GSA DATA REPOSITORY 2015114

\title{
Episodic photic zone euxinia in the northeastern Panthalassic Ocean during the end- Triassic extinction
}

Alex H. Kasprak ${ }^{1}$, Julio Sepúlveda ${ }^{2 \dagger}$, Rosalyn Price-Waldman ${ }^{1}$, Kenneth H. Williford ${ }^{3}$, Shane D. Schoepfer ${ }^{4}$, James W. Haggart ${ }^{5}$, Peter D. Ward ${ }^{6}$, Roger E. Summons ${ }^{2}$, Jessica H. Whiteside ${ }^{7}$ *

${ }^{1}$ Earth, Environmental and Planetary Sciences, Brown University, Providence, RI, 02912, USA

${ }^{2}$ Earth, Atmospheric and Planetary Sciences, Massachusetts Institute of Technology, Cambridge, MA, 02139, USA

${ }^{3}$ Jet Propulsion Laboratory, California Institute of Technology, Pasadena, CA, 91109, USA

${ }^{4}$ Earth and Space Sciences, University of Washington, Seattle, WA, 98195, USA

${ }^{5}$ Geological Survey of Canada - Vancouver, Vancouver, BC, V6B 5J3, Canada

${ }^{6}$ Geology and Geophysics, The University of Adelaide, Adelaide, South Australia 5005, Australia

${ }^{7}$ Ocean and Earth Sciences, National Oceanography Centre Southampton, University of Southampton, Waterfront Campus, European Way, SO14 3ZH, UK

${ }^{\dagger}$ Now at Geological Sciences and Institute for Arctic and Alpine Research, University of Colorado Boulder, 80309, USA

*Corresponding author:

Email: J.Whiteside@soton.ac.uk

\section{Methods}

\subsection{Sample Collection}

Samples were collected in the summer of 2004 at stratigraphic intervals of $\sim 5 \mathrm{~m}$ in the upper Triassic and $\sim 1 \mathrm{~m}$ in the lower Jurassic. The error in stratigraphic height of each sample was lower than $0.5 \mathrm{~m}$ over the nearly $200 \mathrm{~m}$ section, delineated by a metal tape bolted to the outcrop.

\subsection{Cleaning Protocol and Sample Preparation}

Biomarker Sample Prep: Weathered edges were removed using a rock saw, followed by rinses with B-Pure water and acetone, and later sonicated in B-Pure water for $30 \mathrm{~min}$ to remove surface contamination. Samples were dried, crushed with a metal press, and pulverized to a fine power using an agate mortar and pestle. All laboratory equipment was rinsed with high-purity acetone, methanol $(\mathrm{MeOH})$, and dichloromethane (DCM) between samples to avoid cross contamination. Powdered samples were then split for 
bulk elemental analysis and lipid extraction All glassware, aluminum foil, silica, quartz wool and quartz sand were combusted at $500^{\circ} \mathrm{C}$ for at least 12 hours to remove organic contamination; metal tools were rinsed in $\mathrm{MeOH}$ and DCM.

\subsection{Nitrogen Isotope prep}

A subsample of approximately $10 \mathrm{~g}$ selected for a lack of visible fracture fills and surface alteration was taken from each of the 51 samples, cleaned by sonication in ethanol for 1 hour, and in ultrapure deionized water $(>18 \mathrm{M} \Omega)$ three consecutive times. Samples were powdered using an agate ball mill. Powders were acidified overnight at $40^{\circ}$ $\mathrm{C}$ in an excess of $20 \% \mathrm{HCl}$ solution to remove carbonates, then rinsed three times with deionized water and dried overnight at $40^{\circ} \mathrm{C}$.

\subsection{Bulk Carbon analysis as a Check for Consistency with Previous Studies}

Total carbon (TC) and the $\mathrm{C}$ isotopic composition of total organic carbon $\left(\delta^{13} \mathrm{C}_{\mathrm{TOC}}\right)$ were measured on a Costech 4010 elemental analyzer system coupled to a Thermo Finnigan Delta-V-Plus Isotope Ratio Mass Spectrometer at Brown University. $\delta^{13} \mathrm{C}_{\mathrm{TOC}}$ values were compared to an existing record (Williford et al., 2007) to confirm that our samples were consistent with those used in previous studies. TC was measured in whole rock powders, whereas $\delta^{13} \mathrm{C}_{\text {TOC }}$ was analyzed using decalcified samples. At least two replicates were run per sample. $\mathrm{CaCO}_{3}$ was removed by reacting samples with $2 \mathrm{~N} \mathrm{HCl}$ at $60^{\circ} \mathrm{C}$ for 12 hours. Samples were rinsed with water until neutral $\mathrm{pH}$ was reached, and freeze-dried. Total inorganic carbon (TIC) was measured in duplicate using a UIC CM5012 $\mathrm{CO}_{2}$ coulometer. Total organic carbon (TOC) values were derived from the difference between TC and TIC. TOC values derived in our lab were consistent with previous studies.

\subsection{Lipid Extraction and Separation}

Approximately 5-10 g of powdered rock were extracted with DCM: MeOH $(9: 1 \mathrm{v} / \mathrm{v})$ using a Dionex ASE 250 accelerated solvent extraction system. Cells were packed with quartz filters and quartz sand. Before extraction, samples were spiked with $1 \mu \mathrm{g}$ of $\mathrm{d}_{4} \mathrm{C}_{29}$ $\alpha \alpha \alpha$ (20R)-ethylcholestane. The total lipid extract (TLE) was then concentrated, mixed with activated copper powder for 12 hours to remove elemental sulfur, and filtered through a pipette column packed with quartz wool to remove impurities. Copper was activated using $4 \mathrm{~N} \mathrm{HCl}$ for 1 hour, then rinsed with water to neutrality, and finally rinsed with $\mathrm{MeOH}$ and DCM (10x). Asphaltenes were precipitated from TLEs in 10-40 mL of hexane overnight at $\sim 4^{\circ} \mathrm{C}$ and by centrifugation at $2,500 \mathrm{rpm}$ for 30 minutes. The maltene fraction (supernatant) was pipetted out and collected, and the entire process of asphaltene precipitation was repeated three times. Maltenes $(<5 \mathrm{mg})$ were then separated into three fractions using glass pipette columns filled with silica gel. The dead volume (DV) of each column was calculated by the addition of $n$-hexane. Aliphatic hydrocarbons, aromatic hydrocarbons, and polar compounds were eluted in $n$-hexane (3/8 DV), n-hexane:DCM (8:2 v:v, 4 DV), and DCM:MeOH (4:1 v:v, 4 DV), respectively. After separation, the 
aromatic fraction was spiked with $\mathrm{d}_{4} \mathrm{C}_{29} \alpha \alpha \alpha$ (20R)-ethylcholestane, after ensuring a complete separation from the aliphatic fraction previously spiked as a TLE.

1.6. Gas Chromatography - Multiple Reaction Monitoring - Mass Spectrometry $(G C-$ $M R M-M S)$

Aliphatic and aromatic hydrocarbons were analyzed in full scan by GC-MS and by GC-MRM-MS using predetermined precursor-product reactions (See Data Repository [DR] Table 1) on a Micromass AutoSpec Ultima mass spectrometer interfaced to an Agilent $6890 \mathrm{~N}$ gas chromatograph at Massachusetts Institute of Technology.

GC-MS Protocol for Aliphatic Hydrocarbons: GC was fitted with a DB-1 capillary column (60 m; $0.25 \mathrm{~mm}$ I.D.; $0.25 \mu \mathrm{m}$ film thickness; J\&W Scientific) and He was used as the carrier gas. Temperature program: $60^{\circ} \mathrm{C}(2 \mathrm{~min})$ to $150^{\circ} \mathrm{C}$ at $10^{\circ} \mathrm{C} \mathrm{min}^{-1}$, to $315^{\circ} \mathrm{C}$ (held $24 \mathrm{~min}$ ) at $3^{\circ} \mathrm{C} \mathrm{min}^{-1}$.

GC-MS Protocol for Aromatic Hydrocarbons: GC was fitted with a DB-5MS capillary column (60 m; $0.25 \mathrm{~mm}$ I.D.; $0.25 \mu \mathrm{m}$ film thickness; J\&W Scientific) and He was used as the carrier gas. Temperature program was: $60^{\circ} \mathrm{C}(1 \mathrm{~min})$ to $150^{\circ} \mathrm{C}$ at $15^{\circ} \mathrm{C} \mathrm{min}^{-1}$, to $325^{\circ} \mathrm{C}$ (held $39 \mathrm{~min}$ ) at $4^{\circ} \mathrm{C} \mathrm{min}^{-1}$.

Autospec Parameters: The Autospec source was operated in electron ionization (EI, 70 $\mathrm{eV}$ ) mode at $250^{\circ} \mathrm{C}$, with $8 \mathrm{kV}$ accelerating voltage for MRM. Full scan analyses were conducted over a range of $\mathrm{m} / \mathrm{z}$ 50-600. Data were acquired and processed using MassLynx 4.0 (Micromass Ltd.).

Compound Identification: Identification of compounds was achieved by comparison with a synthetic mixture of oils (AGSO standard) that contains all known hopanes and steranes. For isorenieratane and aryl isoprenoids we used bitumens from the Cenomanian-Turonian boundary in Jordan (Sepúlveda et al., 2009) and the end-Permian extinction from Meishan, China (Cao et al., 2009), previously reported to contain these compounds. Biomarker concentrations were quantified by comparison with internal standards. Data Repository Figures 3-5 exhibit representative MRM chromatograms of the compounds analyzed in this study.

\subsection{Nitrogen Isotopes and C:N Data}

Organic carbon and nitrogen isotopes were measured via elemental-analyzer continuous-flow isotope ratio mass spectrometry (EA-CF-IRMS) at the University of Washington's IsoLab facility. 25-45 mg of decalcified powders weighed into tin capsules were combusted in a Costech ECS 4010 Elemental Analyzer, coupled to a ThermoFinnigan 253 mass spectrometer, through a ThermoFinnigan CONFLO III gas interface. Measurements were corrected using calibrated internal laboratory standards. All stable isotope results are presented in standard delta $(\delta)$ notation:

$$
\delta=\left(\mathrm{R}_{\text {sample }} / \mathrm{R}_{\text {std. }-} 1\right) \times 1000
$$


The standard for $\mathrm{N}$ isotope measurements was atmospheric air. Analytical precision based on repeated measurement of standards was $0.34 \%$. Samples were measured in triplicate and presented here with 1 standard deviation error bars.

\section{Biomarker Background}

All biomarker indices used in the main text and in this Data Repository are listed in DR Table 3.

\subsection{Sources of compounds}

This study utilizes steranes (derived from eukaryotic sterols), hopanes (derived from bacterial hopanoids), and isorenieratane (derived from Chlorobi) and its diagenetic products (aryl isoprenoids).

Steranes: Sterols are produced by unicellular and multicellular eukaryotes, where algae are known to produce specific classes. $\mathrm{C}_{27}$ sterols are more abundant in red algae, $\mathrm{C}_{28}$ sterols typically derive from chlorophyll-c containing algae (dinoflagellates, coccolithophores, diatoms) and prasinophytes, and $\mathrm{C}_{29}$ sterols derive from green algae (Peters et al., 2005; Volkman et al., 1994, 1998; Kodner et al., 2008). Therefore the relative contribution of algal steranes and their diagenetic products can be used to investigate relative changes in planktonic communities over geological time scales and across critical boundary transitions (DR Table 2).

Interpretation of $\mathrm{C}_{28}$ steranes: This paper argues that the $\mathrm{C}_{28}$ sterol record is indicative of prasinophytes. Although green algae are characterized by synthesizing $\mathrm{C}_{29}$ sterols in abundance, $\mathrm{C}_{28}$ compounds are the dominant sterols in some prasinophytes (Kodner et al., 2008). The fossil and geochemical record suggests that the major radiation of chlorophyll-c producing algae such as diatoms, dinoflagellates and haptophytes, the main producers of $\mathrm{C}_{28}$ sterols, occurred later in the Jurassic and Cretaceous (Grantham and Wakefield, 1988; Volkman et al., 1998; Schwark and Empt, 2006; Knoll et al., 2007). This hypothesis is supported by palynological records indicating a predominance of prasinophytes in the Early Jurassic (Prauss, 2007).

Hopanes: $\mathrm{C}_{27}-\mathrm{C}_{35}$ hopanes are derived from bacteriohopanepolyols, which are produced almost exclusively by bacteria, and include cyanobacteria, purple non-sulfur bacteria, acetic acid bacteria, methanotrophs, methylotrophs, nitrifying bacteria, planctomycetes, sulfate reducers, and metal-reducing bacteria (Summons et al., 1999; Sinninghe Damsté, et al., 2004; Blumenberg et al., 2006, 2009; Fischer et al., 2005; Härtner et al., 2005; Talbot and Farrimond, 2007). Some classes of hopanes have been tied to specific biosynthetic origins. 2-methyl hopanes, expressed in this study as the 2methylhopane index (2-MeHI, DR Table 3 equation 6), are produced mainly by cyanobacteria (Summons et al., 1999). 3-methyl hopanes, expressed here as the 3methylhopane index (3-MeHI, DR Table 3 equation 7), have been tied to methanotrophic bacteria (Peters et al., 2005). 
Isorenieratene: Isorenieratene is produced as a light-harvesting carotenoid by Chlorobi (Peters et al., 2005). Chlorobi are obligate anaerobic photosynthesizing bacteria, and rely on the presence of reduced sulfur species and sunlight (Peters et al., 2005). Therefore, the presence of isorenieratene and its diagenetic and catagenic products (isorenieratane and aryl isoprenoids) in ancient depositional environments have been widely used as indicators for the occurrence of photic zone euxinia (Cao et al., 2009; Peters et al., 2005; Richoz et al., 2012; Grice et al., 2005). Absolute concentrations were calculated by comparison with an injection standard and normalized to TOC.

\subsection{Proxies for redox and water column stratification}

The Homohopane Index: The homohopane index (HHI, DR Table 3 equation 1) quantifies the abundance of the $\mathrm{C}_{35}$ extended side-chain hopanes relative to all other homohopanes (Peters et al., 2005; Köster et al., 1997). Extended side-chain homohopanes $\left(\mathrm{C}_{31-35}\right)$, originate from functionalized $\mathrm{C}_{35}$ bacteriohopanepolyols and other $\mathrm{C}_{35}$ hopanoids common in bacteria (references in Köster et al., 1997). $C_{35}$ is preferentially preserved in sediments under reducing conditions through sulfurization reactions, whereas it undergoes more efficient degradation under oxic conditions (Köster et al., 1997). Therefore, the relative contribution of $\mathrm{C}_{35}$ can be used as an estimation of the degree of oxygen deficiency in the depositional environment.

$\mathrm{C}_{28}$ 28,30 dinorhopanes: $\mathrm{C}_{28} 28,30$ dinorhopanes (DNH, DR Table 3 equation 2) are thought to be produced by chemoautotrophic bacteria that grow in the anoxic-oxic interface (Peters et al., 2005). High relative contributions of $\mathrm{DNH}$ relative to $\mathrm{C}_{30}$ hopane are well correlated with anoxic, clay-poor sediments (Cao et al., 2009; Peters et al., 2005).

Gammacerane index: The gammacerane index (GI, DR Table 3 equation 3) quantifies the relative contribution of gammacerane over $\mathrm{C}_{30}$ hopane, and is highly specific for marine and non-marine water-column stratification (Peters et al., 2005; Sinninghe Damsté et al., 1995). Gammacerane derives from the reduction of tetrahymanol (Peters et al., 2005; Sinninghe Damsté et al., 1995), a compound found in ciliates thriving in highly stratified water columns, commonly associated with oxygen-reduced environments (Peters et al., 2005).

\section{Preservation of lipid biomarkers}

\subsection{Biodegradation}

DR Figure 2 shows the total ion chromatogram (TIC) of the aliphatic hydrocarbon fraction of representative samples. The presence of an elevated chromatographic baseline and a large unresolved complex mixture (UCM), the absence of alkanes, and the occurrence of steranes and hopanes suggest that many of our samples have been subject to moderate to elevated biodegradation (equivalent to scale 3 or 4) (Peters et al., 2005). The use of GC-MRM-MS allows for accurate identification of compounds such as 
hopanes and steranes, which are more resistant to biodegradation than alkanes and other aliphatic compounds (Peters et al., 2005). In order to avoid potential biases by varying biodegradation, we focused on biomarker ratios rather than in absolute concentrations, except for PZE markers.

\subsection{Thermal Maturity}

Thermal maturity: We estimate thermal maturity by determining the degree of isomerization undergone by steranes and hopanes during burial. The proportion between stereoisomers with the biological (thermally unstable) and geological (thermally stable) configuration can be compared to equilibrium end-point values.

\begin{tabular}{|l|l|l|}
\hline Index (bio/geo) & Range of Utility & $\begin{array}{l}\text { Average Values in } \\
\text { Our Samples }\end{array}$ \\
\hline $\begin{array}{l}\mathrm{C}_{30} \beta \alpha / \alpha \beta \text { ratio } \\
\text { DR } 1 \mathrm{E}\end{array}$ & $\begin{array}{l}100 \% \text { (immature) to } 5 \% \text { (early } \\
\text { peak oil generation) (Peters et } \\
\text { al., 2005) }\end{array}$ & $10 \pm 1 \%$ \\
\hline $\begin{array}{l}\mathrm{C}_{32} \mathrm{~S} / \mathrm{R} \text { ratio } \\
\mathrm{DR} 1 \mathrm{~F}\end{array}$ & $\begin{array}{l}0 \% \text { (immature) to } 60 \% \text { (early oil } \\
\text { generation) (Peters et al., 2005) }\end{array}$ & $58 \pm 1 \%$ \\
\hline $\begin{array}{l}\mathrm{C}_{27} \text { aaa } \mathrm{S} / \mathrm{R} \\
\mathrm{DR} 1 \mathrm{G}\end{array}$ & $\begin{array}{l}\text { 0\% (immature) to 55\% (early oil } \\
\text { generation) (Cao et al., 2009; } \\
\text { Köster et al., 1997) }\end{array}$ & $54 \pm 3 \%$ \\
\hline
\end{tabular}

These indices suggest maturity levels in the early peak oil generation range (Ro\% of about 0.55-0.70; Peters et al., 2005). However, the close clustering of the $\mathrm{C}_{32} \mathrm{~S} / \mathrm{R}$ ratio around $60 \%$ suggests that our samples might be close to the equilibrium end-point. We interpret the $\mathrm{C}_{30} \beta \alpha / \alpha \beta$ as most likely representative of thermal maturity, as the nonthermal maturity factors that influence it, terrestrial source and hypersaline depositional environments (Peters et al., 2005), are likely not a significant factor for this section (Haggart et al., 2001). Hopane, sterane, and aryl isoprenoid biomarkers are relatively more resistant to thermal alteration than other aliphatic biomarkers (Peters et al., 2005), and this level of thermal maturity should not significantly affect their use as environmental and ecologic indicators.

\section{Time span represented by our record}

Our record begins at the base of the Rhaetian stage, defined here as the extinction of the bivalve Monotis (Haggart et al., 2001), a boundary currently estimated to be at 204.0 Ma (Gradstein et al., 2012). The top of the section is bracketed by the initiation of the "positive isotope excursion" (Williford et al., 2007), an event estimated at $200.8 \mathrm{Ma}$ through correlation to the Newark Basin (Whiteside et al., 2010). The latter correlation implies a duration of $\sim 3.2$ million years for our record (see DR Figure 6). A TriassicJurassic boundary at $201.4 \mathrm{Ma}$, such as proposed by correlation to the Newark basin (Whiteside et al., 2010), implies that the period of environmental and ecologic stress following the transition into the Jurassic lasted at least 600,000 years. However, evidence 
from longer records suggest that ecologic stress lasted up to 2 million years after the ETE (Bartolini et al., 2012).

\section{Notes on Figure 1}

Selected studies are those recent studies that best highlight the variability of environmental change in the Tethyan realm, covering the late Rhaetian to late Hettangian.

\begin{tabular}{|c|c|c|c|}
\hline Location & Info & Evidence & Source \\
\hline St. Audrie's Bay & $\begin{array}{l}\text { Nutrient cycle } \\
\text { deposition }\end{array}$ & $\begin{array}{l}\text { Rise in prasinophytes after the } \\
\text { Triassic-Jurassic boundary }\end{array}$ & $\begin{array}{l}\text { van de Schootbrugge } \\
\text { et al., } 2007\end{array}$ \\
\hline St. Audrie's Bay & $\begin{array}{l}\text { Redox } \\
\text { conditions, } \\
\text { nutrient } \\
\text { cycling }\end{array}$ & $\begin{array}{l}\text { Chlorobi-derived biomarkers of } \\
\text { episodic and persistent photic zone } \\
\text { euxinia associated with } \\
\text { perturbations of the carbon and } \\
\text { sulfur cycles }\end{array}$ & Jaraula et al., 2013 \\
\hline Pinhay Bay & Euxinia & Pyrite framboids and faunal data & Wignall, 2001 \\
\hline Frick Swiss Jura & $\begin{array}{l}\text { Euxinia, } \\
\text { nutrient } \\
\text { cycling }\end{array}$ & $\begin{array}{l}\text { Geochemical evidence for } \\
\text { isorieneratane and increased } \\
\text { cyanobacterial production in } \\
\text { middle-Hettangian samples }\end{array}$ & $\begin{array}{l}\text { Schwab \& } \\
\text { Spangenberg, } 2007\end{array}$ \\
\hline $\begin{array}{l}\text { Eiberg Basin } \\
\text { sections, Austria }\end{array}$ & $\begin{array}{l}\text { Redox } \\
\text { conditions }\end{array}$ & $\begin{array}{l}\text { Carbon isotopes and palynology } \\
\text { suggest that terrigenous input } \\
\text { drove anoxic bottom waters }\end{array}$ & $\begin{array}{l}\text { Bonis et al., } 2009 \\
\text { Bonis et al., } 2010\end{array}$ \\
\hline $\begin{array}{l}\text { Eiberg Basin } \\
\text { sections, Austria }\end{array}$ & $\begin{array}{l}\text { Nutrient } \\
\text { cycling }\end{array}$ & $\begin{array}{l}\text { Widespread occurrence of } \\
\text { prasinophytes concurrent with } \\
\text { excursions in the bulk carbon } \\
\text { isotope signature, supporting an } \\
\text { alteration to nutrient cycles }\end{array}$ & $\begin{array}{l}\text { Bonis et al., } 2009 \\
\text { Bonis et al., } 2010\end{array}$ \\
\hline Csovar, Hungary & $\begin{array}{l}\text { Nutrient } \\
\text { cycling }\end{array}$ & $\begin{array}{l}\text { Prasinophyte bloom concurrent } \\
\text { with a negative carbon isotope } \\
\text { excursion and trilete land spore } \\
\text { bloom }\end{array}$ & Haas et al., 2010 \\
\hline $\begin{array}{l}\text { Rosswinkel, } \\
\text { Luxembourg, } \\
\text { Mingolsheim, } \\
\text { Mariental Germany }\end{array}$ & $\begin{array}{l}\text { Redox } \\
\text { conditions, } \\
\text { euxinia, } \\
\text { nutrient } \\
\text { cycling }\end{array}$ & $\begin{array}{l}\text { Shift from oxygenated shales in } \\
\text { the late Rhaetian to anoxic shales } \\
\text { with abundant evidence for the } \\
\text { occurrence of PZE in the } \\
\text { Hettangian for Rosswinkel and } \\
\text { Mariental. Euxinic depositional } \\
\text { conditions coincided with } \\
\text { increased prasinophyte dominance, } \\
\text { consistent with a nutrient } \\
\text { disruption scenario. } \\
\text { The southern German site of } \\
\text { Mingolsheim, however, did not } \\
\text { present evidence for nutrient } \\
\text { disruption or euxinia. }\end{array}$ & Richoz et al., 2012 \\
\hline
\end{tabular}




\section{Notes on Figure 2}

A single sample at $\mathbf{1 2 5 . 6}$ meters exhibited particularly elevated (relative to the entire record) values for the GI, HHI, 28,30 DNH, 2-MeHI, 3-MeHI, as well as an enhanced concentration of isorenieratane. We interpret these signals to represent an interval of particularly exacerbated environmental and ecologic disruption, likely at the peak of the environmental conditions that lead to extinction across the ETE. Contamination by hydrocarbon migration is an unlikely explanation for this change, taking into account the rather homogeneous thermal maturity and lithology of this part of the section. Anomalous TOC, TIC, or hopane and sterane concentrations cannot be invoked either (DR Figure 1A-E), as they are similar to other samples. The potential contribution of soil bacteria to the total pool of bacterial hopanes appears unlikely due to the lack of biomarkers indicative of terrestrial sources, such as an elevated contribution of $\mathrm{C}_{29}$ steranes (Peters et al., 2005), or enhanced concentrations of polycyclic aromatic hydrocarbons (PAHs; data not shown).

Accurate determination of biomarker concentrations in the sample at $32.5 \mathrm{~m}$ was not possible due to the loss of sample during processing. However, ratios derived from MRM-GC-MS data are provided.

\section{References}

Bartolini, A., Guex, J., Spangenberg, J.E., Schoene, B., Taylor, D.G., Schaltegger, U., and Atudorei, V., 2012, Disentangling the Hettangian carbon isotope record: implications for the aftermath of the end-Triassic mass extinction: Geochemistry, Geophysics, Geosystems, v. 13, Q01007.

Blumenberg, M., Krüger, M., Nauhaus, K., Talbot, H.M., Oppermann, B.I., Seifert, R., Pape, T., and Michaelis, W., 2006, Biosynthesis of hopanoids by sulfate-reducing bacteria (genus Desulfovibrio): Environmental Microbiology, v. 8, p. 1220-1227.

Blumenberg, M., Seifert, R., Kasten, S., Bahlmann, E., and Michaelis, W., 2009, Euphotic zone bacterioplankton sources major sedimentary bacteriohopanepolyols in the Holocene Black Sea: Geochimica et Cosmochimica Acta, v. 73, p. 750-766.

Bonis, N. R., Kürschner, W. M.L., and Krystyn, A., 2009, A detailed palynological study of the Triassic-Jurassic transition in key sections of the Eiberg Basin (Northern Calcareous Alps, Austria): Review of Palaeobotany and Palynology, v. 156, p. 376400.

Bonis, N. R., Ruhl, M., and Kurschner, W. M., 2010, Climate change driven black shale deposition during the end-Triassic in the western Tethys: Palaeogeography, Palaeoclimatology, Palaeoecology, v. 290, p. 151-159.

Cao, C., Love, G.D., Hays, L.E., Wang, W., Shen, S., and Summons, R.E., 2009, Biogeochemical evidence for euxinic oceans and ecological disturbance presaging 
the end-Permian mass extinction event: Earth and Planetary Science Letters, v. 281, p. $188-201$.

Fischer, W. W., Summons, R. E., and Pearson, A., 2005, Targeted genomic detection of biosynthetic pathways: anaerobic production of hopanoid biomarkers by a common sedimentary microbe: Geobiology, v. 3, p. 33-40.

Gradstein, F.M., Ogg, J.G., Schmitz, M.D., and Ogg, G.M. (eds.), 2012, The Geologic Time Scale 2012: Oxford, Elsevier, 1144 p.

Grantham, P.J., and Wakefield, L.L., 1988, Variations in the sterane carbon number distributions of marine source rock derived crude oils through geological time: Organic Geochemistry, v. 12, p. 61-73.

Grice, K., Cao, C., Love, G.D., Böttcher, M.E., Twitchett, R.J., Grosjean, E., Summons, R.E., Turgeon, S.C., Dunning, W., and Jin, Y., 2005, Photic zone euxinia during the Permian-Triassic superanoxic event: Science, v. 307, p. 706-709.

Haas, J., Götz, A. E., and Pálfy, J., 2010, Late Triassic to Early Jurassic palaeogeography and eustatic history in the NW Tethyan realm: new insights from sedimentary and organic facies of the Csővár Basin (Hungary): Palaeogeography, Paleoclimatology, Palaeoecology, v. 291, p. 401-409.

Haggart, J.W., Carter, E.S., Beattie, M.J., Bown, P.S., Inkin, R.J., Kring, D.A., Johns, M.J., McNicoll, V.J., Orchard, M.J., Perry, R.S., Schröder-Adams, C.S., Smith, P.L., Suneby, L. B., Tipper, H.W., and Ward, P.D., 2001, Stratigraphy of Triassic/Jurassic boundary strata, Queen Charlotte Islands, British Columbia: potential global system stratotype boundary: IGCP 458 Field Meeting, Taunton, United Kingdom, p. 6-9.

Härtner, T. Straub, K. L., and Kannenberg, E., 2005, Occurrence of hopanoid lipids in anaerobic Geobacter species: FEMS Microbiology Letters, v. 243, p. 59-64.

Jaraula, C.M.B., Grice, K., Twitchett, R.J., Böttcher, M.E., Lemetayer, P., Dastidar, A.G., Opazo, L.F., 2013, Elevated $\mathrm{pCO}_{2}$ leading to Late Triassic extinction, persistent photic zone euxinia, and rising sea levels: Geology, v. 41, p. 955-958.

Knoll, A. H., Summons, R. E., Waldbauer, J. R., and Zumberge, J. E., 2007, The geological succession of primary producers in the oceans; In Evolution of Primary Producers in the Sea, edited by Paul Falowski and Andy Knoll (Academic Press, San Diego).

Kodner, R. B., Pearson, A., Summons, R. E., and Knoll, A. H., 2008, Sterols in red and green algae: quantification, phylogeny, and relevance for the interpretation of geologic steranes: Geobiology, v. 6, p. 411-420.

Köster, J., Van Kaam-Peters, H. M. E., Koopmans, M. P., De Leeuw, J. W., and Sinninghe Damsté, J. S., 1997, Sulphurisation of homohopanoids: Effects on carbon number distribution, speciation, and 22S22R epimer ratios: Geochimica et 
Cosmochimica Acta, v. 61, p. 2431-2452.

Peters, K. E., Walters, C. C. and Moldowan, J. M., 2005, The Biomarker Guide: Volume 2: Biomarkers and Isotopes in Petroleum Exploration and Earth History (2nd Edition): Cambridge, Cambridge University Press, 700 p.

Prauss, M. L., 2007, Availability of reduced nitrogen chemospecies in photic-zone waters as the ultimate cause for fossil prasinophyte prosperity: Palaios, v. 22, p. 489-499.

Rampen, S.W., Schouten, S., Abbas, B., Panoto, F.E., Muyzer, G., Campbell, C.N., Fehling, J., and Sinninghe Damsté, J.S., 2007, On the origin of 24-norcholestanes and their use as age-diagnostic biomarkers: Geology, v. 35, p. 419-422.

Richoz, S., van de Schootbrugge, B., Pross, J., Püttmann, W., Quan, T.M., Lindström, S., Heunisch, C., Fiebig, J., Maquil, R., Schouten, S., Hauzenberger, C.A., and Wignall, P.B., 2012, Hydrogen sulphide poisoning of shallow seas following the end-Triassic extinction: Nature Geoscience, v. 5, p. 1-6.

Schwab, V., and Spangenberg, J., 2007, Molecular and isotopic characterization of biomarkers in the Frick Swiss Jura sediments: a palaeoenvironmental reconstruction on the northern Tethys margin: Organic Geochemistry, v. 38, p. 419-439.

Schwark, L., and Empt, P., 2006, Sterane biomarkers as indicators of Palaeozoic algal evolution and extinction events: Palaeogeography, Palaeoclimatology, Palaeoecology, v. 240, p. 225-236.

Sepulveda, J., Wendler, J., Leider, A., Kuss, H-J., Summons, R.E. and Hinrichs, K-U., 2009, Molecular isotopic evidence of environmental and ecological changes across the Cenomanian-Turonian boundary in the Levant Platform of central Jordan: Organic Geochemistry, v. 40, p. 553-568.

Sinninghe Damsté, J.S., Kenig, F., Koopmans, M.P., Köster, J., Schouten, S., Hayes, J.M., and de Leeuw, J.W., 1995, Evidence for gammacerane as an indicator of water column stratification: Geochimica et Cosmochimica Acta, v. 59, p. 1895-1900.

Sinninghe Damsté, J.S., Rijpstra, W.I.C., Schouten, S., Fuerst, J.A., Jetten, M.S.M., and Strous, M., 2004, The occurrence of hopanoids in planctomycetes: implications for the sedimentary biomarker record: Organic Geochemistry, v. 35, p. 561-566.

Summons, R. E., Jahnke, L. L., Hope, J.M., and Logan, G. A., 1999, 2-Methylhopanoids as biomarkers for cyanobacterial oxygenic photosynthesis: Nature, v. 400, p. 554557.

Talbot, H. M., and Farrimond, P., 2007, Bacterial populations recorded in diverse sedimentary biohopanoid distributions: Organic Geochemistry, v. 38, p. 1212-1225.

van de Schootbrugge, B., Tremolada, F., Rosenthal, Y., Bailey, T.R., Feist-Burkhardt, S., Brinkhuis, H., Pross, J., Kent, D.V., and Falkowski, P.G., 2007, End-Triassic 
calcification crisis and blooms of organic-walled "disaster species": Palaeogeography, Palaeoclimatology, Palaeoecology, v. 244, p. 126-141.

Volkman, J. K., Barrett, S. M., Blackburn, S. I., Mansour, M. P., Sikes, E. L., and Gelin, F., 1998, Microalgal biomarkers: a review of recent research developments: Organic Geochemistry, v. 29, p. 1163-1179.

Volkman, J. K., Barrett, S. M., Dunstan, G. A., and Jeffrey, S. W., 1994, Sterol biomarkers for microalgae from the green algal class Prasinophyceae: Organic Geochemistry, v. 21, p. 1211-1218.

Whiteside, J. H., Olsen, P. E., Eglinton, T., Brookfield, M. E., and Sambrotto, R. N., 2010, Compound-specific carbon isotopes from Earth's largest flood basalt eruptions directly linked to the end-Triassic mass extinction: Proceedings of the National Academy of Sciences, v. 107, p. 6721-6725.

Wignall, P. B., 2001, Sedimentology of the Triassic-Jurassic boundary beds in Pinhay Bay: Proceedings of the Geologists' Association, v. 112, p. 349-360.

Williford, K. H., Foriel, J., Ward, P. D., and Steig, E. J., 2009, Major perturbation in sulfur cycling at the Triassic-Jurassic boundary: Geology, v. 37, p. 835-838.

Williford, K. H., Ward, P.D., Garrison, G. H., and Buick, R., 2007, An extended organic carbon-isotope record across the Triassic-Jurassic boundary in the Queen Charlotte Islands, British Columbia, Canada: Palaeogeography, Palaeoclimatology, Palaeoecology, v. 244, p. 290-296. 
Data Repository Table 1. MRM-GC-MS precursor-product reactions

\begin{tabular}{|c|c|c|}
\hline Precursor mass (Da) & Product mass (Da) & Biomarkers \\
\hline 358 & 217 & $\mathrm{C}_{26}$ Steranes \\
\hline 372 & 217 & $\mathrm{C}_{27}$ Steranes \\
\hline 386 & 217 & $\mathrm{C}_{28}$ Steranes \\
\hline 404 & 221 & $\mathrm{D}_{4} \mathrm{C}_{29}$ Internal std. \\
\hline 400 & 217 & $\mathrm{C}_{29}$ Steranes \\
\hline 414 & 217 & $\mathrm{C}_{30}$ Steranes \\
\hline 426 & 205 & Me- $\mathrm{C}_{30}$ Hopanes \\
\hline 370 & 191 & $\mathrm{C}_{27}$ Hopanes \\
\hline 384 & 191 & $\mathrm{C}_{28}$ Hopanes \\
\hline 398 & 191 & $\mathrm{C}_{29}$ Hopanes \\
\hline 412 & 191 & $\mathrm{C}_{30}$ Hopanes \\
\hline 426 & 191 & $\mathrm{C}_{31}$-Homohopanes \\
\hline 440 & 191 & $\mathrm{C}_{32}$ Homohopanes \\
\hline 454 & 191 & $\mathrm{C}_{33}$ Homohopanes \\
\hline 468 & 191 & $\mathrm{C}_{34}$ Homohopanes \\
\hline 482 & 191 & $\mathrm{C}_{35}$ Homohopanes \\
\hline 246 & 134 & $\mathrm{C}_{18}$ Aryl Isoprenoid \\
\hline 260 & 134 & $\mathrm{C}_{19}$ Aryl Isoprenoid \\
\hline 274 & 134 & $\mathrm{C}_{20}$ Aryl Isoprenoid \\
\hline 288 & 134 & $\mathrm{C}_{21}$ Aryl Isoprenoid \\
\hline 302 & 134 & $\mathrm{C}_{22}$ Aryl Isoprenoid \\
\hline 546 & 134 & Isorenieratane \\
\hline
\end{tabular}

\section{Data Repository Table 2. Sources of Steranes}

\begin{tabular}{|c|c|}
\hline Sterane Class & Most Common Source(s) \\
\hline $\mathrm{C}_{26}$ Steranes & $\begin{array}{l}\text { Typically digenetic products (Peters et al., 2005). Found to be } \\
\text { produced by cold-water diatoms (Rampen et al., 2007). }\end{array}$ \\
\hline $\mathrm{C}_{27}$ Steranes & Red Algae (Peters et al., 2005; Volkman et al., 1998) \\
\hline $\mathrm{C}_{28}$ Steranes & $\begin{array}{l}\text { Chlorophyll-C Containing Algae } \\
\text { (Peters et al., 2005; Volkman et al., 1998): } \\
\text { - Dinoflagellates } \\
\text { - Coccolithophores } \\
\text { - Diatoms } \\
\text { Prasinophytes (Volkman et al., 1994, Kodner et al., 2008) }\end{array}$ \\
\hline $\mathrm{C}_{29}$ Steranes & Green Algae, including terrestrial plants (Kodner et al., 2008) \\
\hline $\mathrm{C}_{30}$ Steranes & Chrysophytes (Peters et al., 2005) \\
\hline
\end{tabular}


Data Repository Table 3. Calculation of indices and ratios. The compounds in the equations refer to the integrated area of the peak in the GC-MRM-MS trace.

\begin{tabular}{|c|c|}
\hline 1. Homohopane Index & $\mathrm{HHI}=\frac{\mathrm{C}_{35} \alpha \beta \mathrm{S}+\mathrm{R}}{\sum \mathrm{C}_{31-35} \alpha \beta \mathrm{S}+\mathrm{R}} \bullet 100$ \\
\hline 2. $C_{28} 28,30$ Bisnorhopane Index & $\mathrm{DNH}=\frac{\mathrm{C}_{28} 28,30 \text { dinor }}{\mathrm{C}_{28} 28,30 \text { dinor }+\mathrm{C}_{30} \alpha \beta}$ \\
\hline 3. Gammacerane Index & $\mathrm{GI}=\frac{\mathrm{C}_{30} \mathrm{Gamma}}{\mathrm{C}_{30} \mathrm{Gamma}+\mathrm{C}_{30} \alpha \beta} \bullet 100$ \\
\hline $\begin{array}{l}\text { 4. } \mathrm{C}_{26}-\mathrm{C}_{30} \text { Steranes : } \\
\mathrm{C}_{27}-\mathrm{C}_{35} \text { Hopanes }\end{array}$ & Ster $:$ Ster + Hop $=\frac{\sum \text { Steranes }(\text { reg) }}{\sum \text { Steranes }(\text { reg })+\text { Hopanes }(\text { reg })}$ \\
\hline 5. $C_{x x}$ Steranes & $\mathrm{C}_{\mathrm{xx}}$ Steranes $=\frac{\sum \mathrm{C}_{\mathrm{xx}} \text { Steranes (all) }}{\sum \mathrm{C}_{26-30} \text { Steranes (all) }}$ \\
\hline 6. 2-Methyl Hopane Index & $2-\mathrm{MeHI}=\frac{\mathrm{C}_{31} 2 \alpha-\mathrm{MeH}}{\mathrm{C}_{30} \alpha \beta+\mathrm{C}_{31} 2 \alpha-\mathrm{MeH}} \bullet 100$ \\
\hline 7. 3-Methyl Hopane Index & $3-\mathrm{MeHI}=\frac{\mathrm{C}_{31} 3 \beta-\mathrm{MeH}}{\mathrm{C}_{30} \alpha \beta+\mathrm{C}_{31} 3 \beta-\mathrm{MeH}} \bullet 100$ \\
\hline 8. $C_{30} \beta \alpha / \alpha \beta$ & $\mathrm{C}_{30} \beta \alpha / \alpha \beta=\frac{\mathrm{C}_{30} \beta \alpha}{\mathrm{C}_{30} \beta \alpha+\mathrm{C}_{30} \alpha \beta} \bullet 100$ \\
\hline 9. $\mathrm{C}_{32} \mathrm{~S} / \mathrm{R}$ & $\mathrm{C}_{32} \mathrm{~S} / \mathrm{R}=\frac{\mathrm{C}_{32} \alpha \beta \mathrm{S}}{\mathrm{C}_{32} \alpha \beta \mathrm{S}+\mathrm{C}_{32} \alpha \beta \mathrm{R}} \bullet 100$ \\
\hline 10. $\mathbf{C}_{27} \alpha \alpha \alpha \mathrm{S} / \mathrm{R}$ & $\mathrm{C}_{27} \alpha \alpha \alpha \mathrm{S} / \mathrm{R}=\frac{\mathrm{C}_{27} \alpha \alpha \alpha \mathrm{S}}{\mathrm{C}_{27} \alpha \alpha \alpha \mathrm{S}+\mathrm{R}} \bullet 100$ \\
\hline 11. Ts/Tm & $\mathrm{Ts} / \mathrm{Tm}=\frac{\mathrm{Ts}}{\mathrm{Ts}+\mathrm{Tm}} \bullet 100$ \\
\hline 12. $\mathrm{C}_{29} \mathrm{Dia} / \mathrm{Reg}$ & $\mathrm{C}_{29}$ Dia $/ \operatorname{Reg}=\frac{\mathrm{C}_{29} \text { Dia S }+\mathrm{C}_{29} \text { Dia R }}{\mathrm{C}_{29}(\mathrm{Dia}+\text { Reg, all })}$ \\
\hline
\end{tabular}


Data Repository Table 4. Biomarker Data for Figure 2

\begin{tabular}{|c|c|c|c|c|c|c|c|c|c|c|c|}
\hline $\begin{array}{c}\text { Stratigraphic } \\
\text { Position }\end{array}$ & $\begin{array}{c}\text { KPF } \\
\text { Sample No. }\end{array}$ & $\begin{array}{c}\text { Homohopane } \\
\text { Index }\end{array}$ & $\begin{array}{c}\text { Gamma/ } \\
\text { (C30+Gamma) }\end{array}$ & $\begin{array}{c}28,30 \mathrm{BNH} / \\
(28,30 \mathrm{BNH}+\mathrm{C} 30)\end{array}$ & $\begin{array}{c}\text { ug/g TOC } \\
\text { [C18-22] }\end{array}$ & $\begin{array}{c}\text { ug/g TOC } \\
\text { [ISO] }\end{array}$ & $\begin{array}{c}\text { C26-30Ster/ } \\
\text { Hop+C26-C30 }\end{array}$ & $\begin{array}{c}\text { Sterane } \\
\text { C28/ } \\
\text { (C26-C30) }\end{array}$ & $\begin{array}{c}\text { Sterane } \\
\text { C29/ } \\
\text { (C26-C30) }\end{array}$ & C31 2-MHI (\%) & C31 3-MHI \\
\hline 7.6 & -270 & 5.1 & 1.7 & 19.1 & 65.18 & 0.00 & 39.9 & 23.4 & 36.6 & 1.11 & 1.3 \\
\hline 15.3 & -250 & 6.5 & 1.8 & 15.6 & 19.12 & 0.00 & 36.9 & 21.4 & 42.7 & 4.14 & 1.6 \\
\hline 23.1 & -230 & 5.5 & 0.6 & 10.4 & 75.15 & 0.00 & 35.0 & 18.6 & 50.4 & 2.04 & 1.4 \\
\hline 27.0 & -220 & 6.0 & 1.1 & 11.9 & 40.64 & 0.00 & 36.6 & 20.9 & 44.0 & 1.40 & 1.6 \\
\hline 30.9 & -210 & 5.6 & 1.0 & 11.9 & & & 41.0 & 20.0 & 44.8 & 1.08 & 1.8 \\
\hline 38.6 & -190 & 4.7 & 0.7 & 9.7 & 16.85 & 0.00 & 37.0 & 18.7 & 45.0 & 1.09 & 1.9 \\
\hline 42.4 & -180 & 5.1 & 1.1 & 11.2 & 40.43 & 0.00 & 34.4 & 19.6 & 44.3 & 1.68 & 1.8 \\
\hline 49.7 & -160 & 5.0 & 1.6 & 10.2 & 87.44 & 0.00 & 32.2 & 19.9 & 45.3 & 1.08 & 1.6 \\
\hline 68.1 & -110 & 6.1 & 1.2 & 7.9 & 63.94 & 0.00 & 32.6 & 18.8 & 45.3 & 1.83 & 2.1 \\
\hline 95.1 & -49.8 & 4.7 & 1.8 & 11.3 & 37.08 & 0.31 & 22.0 & 18.7 & 51.0 & 1.48 & 2.3 \\
\hline 96.9 & -46.5 & 3.6 & 0.2 & 8.3 & 37.92 & 0.00 & 23.7 & 16.1 & 54.1 & 0.55 & 1.8 \\
\hline 99.3 & -41.9 & 3.9 & 0.6 & 15.1 & 24.79 & 0.00 & 26.3 & 17.9 & 51.9 & 0.77 & 1.7 \\
\hline 100.8 & -39.1 & 4.0 & 1.9 & 4.9 & 25.80 & 2.19 & 24.2 & 17.9 & 49.6 & 0.97 & 1.8 \\
\hline 103.0 & -35 & 8.2 & 2.4 & 22.4 & 8.09 & 0.00 & 31.2 & 21.3 & 45.0 & 2.76 & 1.7 \\
\hline 105.1 & -31 & 3.4 & 0.3 & 5.1 & 35.15 & 0.00 & 28.8 & 17.3 & 51.0 & 1.02 & 2.5 \\
\hline 114.2 & -14 & 14.8 & 0.7 & 12.2 & 84.13 & 20.13 & 18.4 & 20.9 & 40.9 & 6.17 & 2.2 \\
\hline 115.2 & -12 & 15.6 & 1.4 & 26.2 & 197.00 & 10.35 & 21.5 & 20.3 & 42.3 & 13.36 & 4.6 \\
\hline 116.5 & -9.5 & 7.7 & 2.1 & 18.6 & 78.58 & 0.43 & 24.3 & 21.1 & 42.2 & 2.70 & 2.4 \\
\hline 117.4 & -7.6 & 7.9 & 1.7 & 14.4 & 55.20 & 0.00 & 22.5 & 19.1 & 43.9 & 4.04 & 2.8 \\
\hline 118.5 & -5.3 & 8.7 & 1.5 & 15.1 & 37.23 & 0.00 & 23.7 & 20.6 & 44.3 & 4.28 & 2.3 \\
\hline 119.0 & -4.3 & 7.0 & 1.6 & 16.2 & 87.45 & 0.00 & 25.9 & 21.0 & 42.2 & 3.13 & 2.0 \\
\hline 120.5 & -1 & 7.4 & 1.3 & 14.9 & 7.65 & 0.00 & 24.9 & 21.4 & 45.3 & 1.55 & 1.7 \\
\hline 121.9 & 2.8 & 13.0 & 2.1 & 28.6 & 67.19 & 5.28 & 29.6 & 22.2 & 45.8 & 4.12 & 3.3 \\
\hline 122.5 & 5 & 7.5 & 0.9 & 26.9 & 101.78 & 1.04 & 23.4 & 22.4 & 47.1 & 1.28 & 2.2 \\
\hline 123.2 & 7.4 & 8.1 & 1.4 & 30.8 & 168.40 & 2.96 & 24.4 & 21.7 & 47.5 & 2.22 & 2.4 \\
\hline 123.9 & 10.1 & 15.2 & 1.5 & 26.4 & 70.42 & 4.83 & 22.7 & 19.9 & 43.5 & 13.05 & 4.7 \\
\hline 124.7 & 13.2 & 10.2 & 1.9 & 31.3 & 136.86 & 7.22 & 26.5 & 21.4 & 46.8 & 2.74 & 1.7 \\
\hline 125.1 & 15 & 9.3 & 1.6 & 32.8 & 217.51 & 6.21 & 19.6 & 21.5 & 48.3 & 1.61 & 2.2 \\
\hline
\end{tabular}




$\begin{array}{lccccccccccc}125.6 & 17.3 & 20.3 & 9.4 & 43.8 & 279.49 & 86.03 & 22.2 & 19.5 & 44.0 & 28.68 & 13.4 \\ 126.4 & 21 & 6.7 & 1.9 & 25.6 & 6.52 & 0.00 & 30.4 & 21.4 & 46.1 & 1.18 & 1.6 \\ 126.6 & 22 & 9.8 & 1.8 & 25.0 & 244.22 & 6.95 & 29.9 & 21.9 & 47.9 & 2.36 & 1.9 \\ 126.9 & 23.6 & 12.3 & 3.0 & 29.9 & 158.71 & 8.38 & 28.1 & 22.0 & 45.4 & 3.45 & 2.2 \\ 127.1 & 24.5 & 10.4 & 1.9 & 26.5 & & & 26.6 & 21.4 & 46.2 & 2.49 & 1.8 \\ 127.5 & 26.8 & 9.0 & 1.7 & 22.1 & 61.31 & 1.23 & 27.7 & 23.0 & 46.2 & 2.73 & 1.8 \\ 128.2 & 30.5 & 12.3 & 2.3 & 18.0 & 154.24 & 15.79 & 32.8 & 20.8 & 45.2 & 4.52 & 3.4 \\ 128.5 & 32.2 & 10.2 & 1.3 & 23.0 & 40.10 & 8.33 & 38.1 & 21.1 & 43.3 & 9.14 & 4.4 \\ 128.9 & 34.6 & 9.7 & 2.3 & 22.1 & 32.25 & 4.03 & 32.0 & 22.0 & 43.9 & 5.14 & 3.5 \\ 130.3 & 42.7 & 9.2 & 2.2 & 21.1 & 64.26 & 3.64 & 28.8 & 21.1 & 43.1 & 8.78 & 4.1 \\ 130.6 & 44.1 & 6.5 & 0.9 & 22.8 & 102.21 & 1.63 & 23.8 & 21.5 & 46.5 & 2.20 & 1.4 \\ 131.2 & 47.9 & 9.5 & 1.8 & 17.5 & 134.59 & 3.84 & 31.9 & 21.9 & 44.1 & 0.86 & 1.3 \\ 133.7 & 60.4 & 4.0 & 0.3 & 14.7 & 0.00 & 0.00 & 24.4 & 15.2 & 52.4 & 0.54 & 2.3 \\ 134.6 & 64.3 & 5.2 & 1.1 & 25.0 & 151.54 & 0.00 & 21.9 & 21.2 & 46.5 & 3.15 \\ 136.0 & 70.4 & 6.7 & 0.7 & 10.7 & 4.30 & 0.00 & 28.0 & 18.6 & 47.0 & 2.15 & 1.8 \\ 139.6 & 82.9 & 9.1 & 1.7 & 5.5 & 190.56 & 3.44 & 28.4 & 22.0 & 45.3 & 2.79 & 1.7 \\ 139.7 & 83.2 & 5.2 & 0.6 & 12.5 & 78.31 & 0.00 & 34.9 & 19.4 & 47.1 & 1.24 \\ 140.5 & 85.5 & 8.9 & 1.4 & 17.1 & 50.77 & 0.57 & 27.5 & 22.9 & 45.0 & 1.96 & 1.9\end{array}$


Data Repository Table 5. N Isotopic Data for Figure 2

\begin{tabular}{|c|c|c|}
\hline & $\delta 15 \mathrm{~N}$ vs & \\
\hline Sample No. & Air N2 (permil) & SD \\
\hline KPF -270 & 2.32 & 0.11 \\
\hline KPF -250 & 0.25 & 0.10 \\
\hline KPF -240 & 0.76 & 0.19 \\
\hline KPF -230 & 1.31 & 0.22 \\
\hline KPF -220 & 2.24 & 0.12 \\
\hline KPF -210 & 4.16 & 0.09 \\
\hline KPF -200 & 3.88 & 0.03 \\
\hline KPF -190 & 2.56 & 0.43 \\
\hline KPF -180 & 3.78 & 0.25 \\
\hline KPF -160 & 3.68 & 0.39 \\
\hline KPF -150 & 2.82 & 0.18 \\
\hline KPF -120 & 4.17 & 0.11 \\
\hline KPF -110 & 3.92 & 0.10 \\
\hline KPF -49.8 & 3.20 & 0.14 \\
\hline KPF -46.5 & 0.76 & 0.75 \\
\hline KPF -41.9 & -0.23 & 0.45 \\
\hline KPF -39.1 & -0.40 & 0.10 \\
\hline KPF -35 & 1.01 & 0.11 \\
\hline KPF -31 & 0.31 & 0.20 \\
\hline KPF -29.1 & -1.29 & 0.40 \\
\hline $\mathrm{KPF}-14$ & 0.84 & 0.22 \\
\hline KPF -12 & 0.88 & 0.02 \\
\hline KPF -9.5 & 2.24 & 0.11 \\
\hline KPF -7.6 & 2.04 & 0.05 \\
\hline KPF -5.3 & -0.10 & 0.30 \\
\hline KPF -4.3 & 2.00 & 0.08 \\
\hline KPF -1 & 0.70 & 0.23 \\
\hline KPF 2.8 & 0.90 & 0.13 \\
\hline KPF 5.0 & 0.68 & 0.14 \\
\hline KPF 7.4 & 1.71 & 0.24 \\
\hline KPF 10.1 & 0.03 & 0.54 \\
\hline KPF 13.2 & -0.48 & 1.13 \\
\hline KPF 15 & 1.45 & 0.02 \\
\hline KPF 17.3 & 0.68 & 0.70 \\
\hline KPF 21 & 0.27 & 0.45 \\
\hline KPF 22 & 0.96 & 0.29 \\
\hline KPF 23.6 & 2.37 & 0.06 \\
\hline KPF 24.5 & 0.75 & 0.14 \\
\hline KPF 26.8 & 1.51 & 0.10 \\
\hline
\end{tabular}




$\begin{array}{lcl}\text { KPF 30.5 } & 0.62 & 0.14 \\ \text { KPF 32.2 } & 0.85 & 0.26 \\ \text { KPF 34.6 } & 0.30 & 0.17 \\ \text { KPF 42.7 } & -0.75 & 0.10 \\ \text { KPF 44.1 } & 0.50 & 0.14 \\ \text { KPF 47.9 } & -0.23 & 0.22 \\ \text { KPF 60.4 } & -0.40 & 1.06 \\ \text { KPF 64.3 } & 0.68 & 0.28 \\ \text { KPF 70.4 } & 1.18 & 0.10 \\ \text { KPF 82.9 } & 1.59 & 0.12 \\ \text { KPF 83.2 } & 2.39 & 0.54 \\ \text { KPF 85.5 } & 1.21 & 0.04\end{array}$


Data Repository Table 6. Carbon, Biomarker, and Isotopic data for DR Figure 1 and DR Figure 6.

\begin{tabular}{|c|c|c|c|c|c|}
\hline $\begin{array}{c}\text { KPF } \\
\text { Sample No. }\end{array}$ & $\begin{array}{c}\text { Stratigraphic } \\
\text { Position }\end{array}$ & \%C Inorg & $\% \mathrm{C}$ Org & $\begin{array}{l}\text { ug/g TOC } \\
\text { [hopanes] }\end{array}$ & $\begin{array}{l}\text { ug/g TOC } \\
\text { [steranes] }\end{array}$ \\
\hline-270 & 7.6 & 2.420 & 9.903 & 2.05 & 23.41 \\
\hline-250 & 15.3 & 5.099 & 3.371 & 66.31 & 42.16 \\
\hline-230 & 23.1 & 1.920 & 1.194 & 453.11 & 275.81 \\
\hline-220 & 27.0 & 0.108 & 2.244 & 152.62 & 97.04 \\
\hline-210 & 30.9 & 0.300 & 2.933 & 188.73 & 141.94 \\
\hline-190 & 38.6 & 0.759 & 1.154 & 413.69 & 261.73 \\
\hline-180 & 42.4 & 0.147 & 3.110 & 437.07 & 253.94 \\
\hline-160 & 49.7 & 0.140 & 1.716 & 595.81 & 300.91 \\
\hline-110 & 68.1 & 0.277 & 3.786 & 298.34 & 165.08 \\
\hline-49.8 & 95.1 & 0.302 & 2.216 & 397.65 & 141.35 \\
\hline-46.5 & 96.9 & 0.151 & 0.733 & 422.86 & 160.60 \\
\hline-41.9 & 99.3 & 0.501 & 0.444 & 92.76 & 38.66 \\
\hline-39.1 & 100.8 & 0.001 & 0.151 & 315.94 & 121.36 \\
\hline-35 & 103.0 & 0.426 & 0.975 & 132.71 & 63.66 \\
\hline-31 & 105.1 & 0.232 & 0.369 & 301.65 & 140.60 \\
\hline-14 & 114.2 & 0.322 & 2.434 & 262.40 & 103.32 \\
\hline-12 & 115.2 & 0.700 & 1.885 & 38.80 & 17.28 \\
\hline-9.5 & 116.5 & 0.385 & 9.457 & 50.98 & 21.82 \\
\hline-7.6 & 117.4 & 0.000 & 4.061 & 80.75 & 31.49 \\
\hline-5.3 & 118.5 & 0.528 & 2.192 & 23.64 & 9.69 \\
\hline-4.3 & 119.0 & 0.036 & 5.824 & 76.11 & 34.46 \\
\hline-1 & 120.5 & 0.600 & 4.014 & 130.27 & 54.49 \\
\hline 2.8 & 121.9 & 1.121 & 1.624 & 50.69 & 28.36 \\
\hline 5 & 122.5 & 0.401 & 2.354 & 304.15 & 124.56 \\
\hline 7.4 & 123.2 & 0.779 & 2.246 & 315.13 & 138.10 \\
\hline 10.1 & 123.9 & 0.785 & 2.161 & 43.25 & 20.09 \\
\hline 13.2 & 124.7 & 0.545 & 1.439 & 358.98 & 158.89 \\
\hline 15 & 125.1 & 0.872 & 2.508 & 367.23 & 126.71 \\
\hline 17.3 & 125.6 & 0.083 & 1.810 & 315.52 & 114.37 \\
\hline 21 & 126.4 & 0.124 & 0.139 & 375.55 & 185.02 \\
\hline 22 & 126.6 & 0.438 & 0.611 & 426.22 & 208.65 \\
\hline 23.6 & 126.9 & 0.154 & 4.770 & 202.04 & 93.67 \\
\hline 24.5 & 127.1 & 0.627 & 2.138 & & \\
\hline 26.8 & 127.5 & 0.385 & 1.556 & 371.20 & 167.30 \\
\hline 30.5 & 128.2 & 0.211 & 1.557 & 302.23 & 166.46 \\
\hline 32.2 & 128.5 & 1.040 & 1.576 & 42.29 & 28.74 \\
\hline 34.6 & 128.9 & 0.742 & 1.827 & 286.71 & 161.37 \\
\hline 42.7 & 130.3 & 0.376 & 1.049 & 137.72 & 69.09 \\
\hline 44.1 & 130.6 & 0.440 & 1.845 & 369.31 & 138.60 \\
\hline 47.9 & 131.2 & 0.006 & 0.403 & 313.04 & 158.68 \\
\hline 60.4 & 133.7 & 0.366 & 0.655 & 471.49 & 197.76 \\
\hline 64.3 & 134.6 & 0.309 & 2.001 & 106.62 & 36.86 \\
\hline 70.4 & 136.0 & 1.271 & 3.257 & 238.49 & 101.11 \\
\hline
\end{tabular}




$\begin{array}{llllll}82.9 & 139.6 & 0.292 & 6.411 & 213.17 & 98.87 \\ 83.2 & 139.7 & 0.416 & 1.026 & 379.51 & 225.68 \\ 85.5 & 140.5 & 3.150 & 2.490 & 307.71 & 134.36\end{array}$

\begin{tabular}{|c|c|c|c|c|c|c|}
\hline $\begin{array}{c}\text { KPF } \\
\text { Sample No. }\end{array}$ & $\begin{array}{c}\text { Stratigraphic } \\
\text { Position }\end{array}$ & $\begin{array}{c}\text { Hopane } \\
\text { C30 ba/ab }\end{array}$ & $\begin{array}{l}\text { Hopane } \\
\text { C32 S/R }\end{array}$ & $\begin{array}{c}\text { Sterane } \\
\text { C27 Reg aaa S/R }\end{array}$ & $\begin{array}{c}\text { Hopane } \\
\text { Ts/Tm }\end{array}$ & $\begin{array}{c}\text { Sterane } \\
\text { C29 Dia/Reg }\end{array}$ \\
\hline-270 & 7.6 & 6.5 & 56.5 & 53.7 & 50.3 & 11.8 \\
\hline-250 & 15.3 & 6.9 & 57.8 & 54.8 & 49.6 & 18.5 \\
\hline-230 & 23.1 & 7.3 & 57.6 & 55.8 & 41.6 & 17.3 \\
\hline-220 & 27.0 & 7.4 & 57.5 & 54.4 & 39.3 & 17.0 \\
\hline-210 & 30.9 & 8.0 & 57.5 & 54.3 & 27.5 & 14.3 \\
\hline-190 & 38.6 & 8.7 & 57.9 & 53.6 & 24.9 & 13.6 \\
\hline-180 & 42.4 & 8.4 & 57.9 & 54.7 & 25.6 & 16.1 \\
\hline-160 & 49.7 & 8.9 & 57.6 & 52.6 & 19.3 & 12.8 \\
\hline-110 & 68.1 & 8.5 & 58.4 & 55.7 & 22.6 & 19.3 \\
\hline-49.8 & 95.1 & 11.4 & 58.5 & 53.5 & 22.1 & 26.0 \\
\hline-46.5 & 96.9 & 9.3 & 58.6 & 52.0 & 27.5 & 21.5 \\
\hline-41.9 & 99.3 & 9.5 & 58.7 & 53.1 & 18.1 & 17.7 \\
\hline-39.1 & 100.8 & 8.8 & 57.9 & 49.7 & 26.9 & 20.4 \\
\hline-35 & 103.0 & 8.4 & 58.0 & 54.0 & 22.1 & 12.1 \\
\hline-31 & 105.1 & 9.4 & 57.6 & 54.8 & 23.5 & 17.9 \\
\hline-14 & 114.2 & 8.7 & 53.9 & 63.1 & 38.1 & 57.1 \\
\hline-12 & 115.2 & 13.4 & 56.3 & 57.7 & 35.5 & 50.0 \\
\hline-9.5 & 116.5 & 9.7 & 58.1 & 57.3 & 33.0 & 32.5 \\
\hline-7.6 & 117.4 & 9.4 & 57.9 & 57.2 & 33.2 & 33.0 \\
\hline-5.3 & 118.5 & 10.5 & 57.0 & 56.5 & 35.4 & 32.4 \\
\hline-4.3 & 119.0 & 9.5 & 58.1 & 56.5 & 33.8 & 29.6 \\
\hline-1 & 120.5 & 10.1 & 58.2 & 56.5 & 28.6 & 26.8 \\
\hline 2.8 & 121.9 & 12.2 & 57.2 & 53.6 & 22.7 & 33.0 \\
\hline 5 & 122.5 & 10.6 & 58.1 & 53.9 & 19.6 & 30.3 \\
\hline 7.4 & 123.2 & 11.1 & 56.9 & 55.0 & 21.0 & 32.1 \\
\hline 10.1 & 123.9 & 12.5 & 56.0 & 58.7 & 35.3 & 47.5 \\
\hline 13.2 & 124.7 & 10.3 & 57.7 & 54.8 & 21.0 & 25.5 \\
\hline 15 & 125.1 & 10.2 & 58.3 & 55.4 & 20.2 & 35.3 \\
\hline 17.3 & 125.6 & 12.1 & 56.0 & 60.6 & 36.2 & 43.8 \\
\hline 21 & 126.4 & 9.5 & 58.2 & 48.1 & 20.6 & 17.9 \\
\hline 22 & 126.6 & 10.0 & 58.4 & 52.9 & 23.0 & 19.1 \\
\hline 23.6 & 126.9 & 9.7 & 58.6 & 54.5 & 21.9 & 23.2 \\
\hline 24.5 & 127.1 & 10.2 & 58.1 & 54.3 & 21.4 & 22.1 \\
\hline 26.8 & 127.5 & 10.6 & 58.3 & 53.8 & 24.0 & 22.0 \\
\hline 30.5 & 128.2 & 9.9 & 57.9 & 55.3 & 33.0 & 24.2 \\
\hline 32.2 & 128.5 & 11.3 & 56.6 & 52.9 & 37.2 & 25.4 \\
\hline 34.6 & 128.9 & 10.6 & 57.3 & 53.7 & 35.2 & 27.3 \\
\hline 42.7 & 130.3 & 10.6 & 57.5 & 55.4 & 32.1 & 34.3 \\
\hline 44.1 & 130.6 & 10.3 & 57.7 & 53.8 & 23.1 & 22.3 \\
\hline 47.9 & 131.2 & 8.5 & 58.7 & 54.2 & 28.7 & 14.6 \\
\hline
\end{tabular}




$\begin{array}{lllllll}60.4 & 133.7 & 8.8 & 58.5 & 54.4 & 29.4 & 26.5 \\ 64.3 & 134.6 & 9.7 & 57.2 & 52.5 & 29.5 & 27.4 \\ 70.4 & 136.0 & 9.2 & 57.9 & 53.7 & 22.0 & 14.2 \\ 82.9 & 139.6 & 9.7 & 57.5 & 53.3 & 23.5 & 21.1 \\ 83.2 & 139.7 & 8.3 & 57.1 & 54.4 & 22.7 & 14.9 \\ 85.5 & 140.5 & 10.0 & 57.4 & 53.0 & 20.7 & 19.2\end{array}$

\begin{tabular}{|c|c|c|c|c|c|c|}
\hline $\begin{array}{c}\text { KPF } \\
\text { Sample No. }\end{array}$ & $\begin{array}{c}\text { Stratigraphic } \\
\text { Position }\end{array}$ & $\begin{array}{c}\text { Sterane } \\
\text { C26/(C26-30) }\end{array}$ & $\begin{array}{c}\text { Sterane } \\
\text { C27/(C26-30) }\end{array}$ & $\begin{array}{c}\text { Sterane } \\
\text { C28/(C26-C30) }\end{array}$ & $\begin{array}{c}\text { Sterane } \\
\text { C29/(C26-C30) }\end{array}$ & $\begin{array}{c}\text { Sterane } \\
\text { C30/(C26-C30) }\end{array}$ \\
\hline-270 & 7.6 & 3.7 & 32.7 & 23.4 & 36.6 & 3.7 \\
\hline-250 & 15.3 & 3.2 & 26.7 & 21.4 & 42.7 & 6.0 \\
\hline-230 & 23.1 & 2.2 & 24.3 & 18.6 & 50.4 & 4.5 \\
\hline-220 & 27.0 & 3.0 & 27.6 & 20.9 & 44.0 & 4.5 \\
\hline-210 & 30.9 & 2.7 & 28.2 & 20.0 & 44.8 & 4.3 \\
\hline-190 & 38.6 & 2.3 & 30.0 & 18.7 & 45.0 & 4.0 \\
\hline-180 & 42.4 & 2.6 & 28.5 & 19.6 & 44.3 & 5.0 \\
\hline-160 & 49.7 & 2.0 & 28.4 & 19.9 & 45.3 & 4.3 \\
\hline-110 & 68.1 & 3.5 & 26.4 & 18.8 & 45.3 & 6.0 \\
\hline-49.8 & 95.1 & 2.3 & 24.0 & 18.7 & 51.0 & 4.0 \\
\hline-46.5 & 96.9 & 1.6 & 25.4 & 16.1 & 54.1 & 2.9 \\
\hline-41.9 & 99.3 & 2.1 & 25.4 & 17.9 & 51.9 & 2.7 \\
\hline-39.1 & 100.8 & 1.8 & 27.8 & 17.9 & 49.6 & 3.0 \\
\hline-35 & 103.0 & 2.0 & 27.1 & 21.3 & 45.0 & 4.7 \\
\hline-31 & 105.1 & 2.1 & 26.2 & 17.3 & 51.0 & 3.3 \\
\hline-14 & 114.2 & 6.6 & 21.6 & 20.9 & 40.9 & 9.9 \\
\hline-12 & 115.2 & 7.0 & 21.8 & 20.3 & 42.3 & 8.6 \\
\hline-9.5 & 116.5 & 5.7 & 25.7 & 21.1 & 42.2 & 5.3 \\
\hline-7.6 & 117.4 & 5.1 & 24.3 & 19.1 & 43.9 & 7.6 \\
\hline-5.3 & 118.5 & 4.8 & 23.6 & 20.6 & 44.3 & 6.6 \\
\hline-4.3 & 119.0 & 5.5 & 25.8 & 21.0 & 42.2 & 5.6 \\
\hline-1 & 120.5 & 4.1 & 24.2 & 21.4 & 45.3 & 5.0 \\
\hline 2.8 & 121.9 & 3.6 & 22.3 & 22.2 & 45.8 & 6.1 \\
\hline 5 & 122.5 & 2.6 & 23.5 & 22.4 & 47.1 & 4.4 \\
\hline 7.4 & 123.2 & 2.7 & 23.1 & 21.7 & 47.5 & 4.9 \\
\hline 10.1 & 123.9 & 6.7 & 21.5 & 19.9 & 43.5 & 8.4 \\
\hline 13.2 & 124.7 & 2.3 & 23.4 & 21.4 & 46.8 & 6.0 \\
\hline 15 & 125.1 & 3.1 & 22.0 & 21.5 & 48.3 & 5.1 \\
\hline 17.3 & 125.6 & 4.2 & 19.1 & 19.5 & 44.0 & 13.2 \\
\hline 21 & 126.4 & 1.8 & 27.2 & 21.4 & 46.1 & 3.5 \\
\hline 22 & 126.6 & 2.3 & 22.3 & 21.9 & 47.9 & 5.6 \\
\hline 23.6 & 126.9 & 2.7 & 23.1 & 22.0 & 45.4 & 6.7 \\
\hline 24.5 & 127.1 & 2.5 & 24.0 & 21.4 & 46.2 & 5.9 \\
\hline 26.8 & 127.5 & 2.4 & 23.6 & 23.0 & 46.2 & 4.9 \\
\hline 30.5 & 128.2 & 3.0 & 24.2 & 20.8 & 45.2 & 6.8 \\
\hline 32.2 & 128.5 & 4.3 & 24.4 & 21.1 & 43.3 & 6.9 \\
\hline 34.6 & 128.9 & 4.4 & 22.7 & 22.0 & 43.9 & 7.0 \\
\hline
\end{tabular}




$\begin{array}{lllllll}42.7 & 130.3 & 4.3 & 23.7 & 21.1 & 43.1 & 7.7 \\ 44.1 & 130.6 & 2.5 & 24.4 & 21.5 & 46.5 & 5.1 \\ 47.9 & 131.2 & 2.0 & 27.0 & 21.9 & 44.1 & 5.0 \\ 60.4 & 133.7 & 1.7 & 27.7 & 15.2 & 52.4 & 3.1 \\ 64.3 & 134.6 & 2.3 & 26.3 & 21.2 & 46.5 & 3.7 \\ 70.4 & 136.0 & 2.1 & 27.7 & 18.6 & 47.0 & 4.7 \\ 82.9 & 139.6 & 2.3 & 25.1 & 22.0 & 45.3 & 5.3 \\ 83.2 & 139.7 & 2.2 & 26.3 & 19.4 & 47.1 & 5.0 \\ 85.5 & 140.5 & 2.1 & 24.6 & 22.9 & 45.0 & 5.4\end{array}$

$\begin{array}{cccc}\text { KPF } & \text { Stratigraphic } & & \\ \text { Sample No. } & \text { Position } & \mathbf{8 1 3 C} & \text { SD } \\ -270 & 7.6 & -28.388 & 0.077 \\ -250 & 15.3 & -30.072 & 0.013 \\ -230 & 23.1 & -29.318 & 0.397 \\ -220 & 27.0 & -29.963 & 0.085 \\ -210 & 30.9 & -29.928 & 0.019 \\ -190 & 38.6 & -28.866 & 0.174 \\ -180 & 42.4 & -30.077 & 0.168 \\ -160 & 49.7 & -29.813 & 0.000 \\ -110 & 68.1 & -29.639 & 0.128 \\ -49.8 & 95.1 & -29.447 & 0.154 \\ -46.5 & 96.9 & -29.180 & 0.518 \\ -41.9 & 99.3 & -29.243 & 0.730 \\ -39.1 & 100.8 & -30.283 & 1.009 \\ -35 & 103.0 & -29.542 & 0.213 \\ -31 & 105.1 & -30.153 & 0.180 \\ -14 & 114.2 & -30.341 & 0.151 \\ -12 & 115.2 & -30.090 & 0.080 \\ -9.5 & 116.5 & -29.982 & 0.074 \\ -7.6 & 117.4 & -29.707 & 0.116 \\ -5.3 & 118.5 & -29.744 & 0.064 \\ -4.3 & 119.0 & -29.949 & 0.055 \\ -1 & 120.5 & -30.365 & 0.025 \\ 2.8 & 121.9 & -30.077 & 0.011 \\ 5 & 122.5 & -29.372 & 0.072 \\ 7.4 & 123.2 & -28.919 & 0.201 \\ 10.1 & 123.9 & -30.014 & 0.007 \\ 13.2 & 124.7 & -29.548 & 0.103 \\ 15 & 125.1 & -29.352 & 0.278 \\ 17.3 & 125.6 & -29.480 & 0.368 \\ 21 & 126.4 & -28.401 & 1.522 \\ 22 & 126.6 & -28.566 & 0.058 \\ 23.6 & 126.9 & -29.973 & 0.117 \\ 24.5 & 127.1 & -29.620 & 0.007 \\ 26.8 & 127.5 & -28.498 & 0.116\end{array}$




$\begin{array}{llll}30.5 & 128.2 & -29.851 & 0.072 \\ 32.2 & 128.5 & -30.034 & 0.217 \\ 34.6 & 128.9 & -29.965 & 0.121 \\ 42.7 & 130.3 & -29.350 & 0.093 \\ 44.1 & 130.6 & -30.034 & 0.145 \\ 47.9 & 131.2 & -27.608 & 0.497 \\ 60.4 & 133.7 & -28.202 & 0.464 \\ 64.3 & 134.6 & -26.112 & 0.061 \\ 70.4 & 136.0 & -30.013 & 0.010 \\ 82.9 & 139.6 & -30.023 & 0.017 \\ 83.2 & 139.7 & -29.344 & 0.116 \\ 85.5 & 140.5 & -28.244 & 0.163\end{array}$

\begin{tabular}{|c|c|c|}
\hline Sample No. & $\mathbf{C} / \mathbf{N}$ & SD \\
\hline KPF -270 & 38.40 & 0.50 \\
\hline KPF -250 & 11.68 & 0.46 \\
\hline KPF -240 & 7.25 & 0.22 \\
\hline KPF -230 & 8.97 & 0.24 \\
\hline KPF -220 & 12.71 & 0.61 \\
\hline KPF -210 & 25.42 & 0.41 \\
\hline KPF -200 & 28.01 & 0.58 \\
\hline KPF -190 & 9.49 & 0.33 \\
\hline KPF -180 & 22.91 & 1.07 \\
\hline KPF -160 & 25.97 & 0.65 \\
\hline KPF -150 & 19.37 & 0.13 \\
\hline KPF -120 & 29.52 & 0.23 \\
\hline KPF -110 & 28.93 & 0.25 \\
\hline KPF -49.8 & 29.62 & 1.64 \\
\hline KPF -46.5 & 14.32 & 0.61 \\
\hline KPF -41.9 & 1.78 & 0.16 \\
\hline KPF -39.1 & 2.84 & 0.03 \\
\hline KPF -35 & 14.01 & 0.27 \\
\hline KPF -31 & 4.80 & 0.08 \\
\hline KPF -29.1 & 3.20 & 0.06 \\
\hline KPF -14 & 25.45 & 1.30 \\
\hline KPF -12 & 26.99 & 1.18 \\
\hline KPF -9.5 & 46.13 & 0.71 \\
\hline KPF -7.6 & 0.12 & 0.01 \\
\hline KPF -5.3 & 22.05 & 0.28 \\
\hline KPF -4.3 & 44.83 & 0.36 \\
\hline KPF -1 & 31.19 & 0.57 \\
\hline KPF 2.8 & 21.45 & 0.89 \\
\hline KPF 5.0 & 28.62 & 0.53 \\
\hline KPF 7.4 & 38.30 & 12.98 \\
\hline KPF 10.1 & 21.63 & 0.09 \\
\hline KPF 13.2 & 18.48 & 0.91 \\
\hline
\end{tabular}




$\begin{array}{ccc}\text { KPF 15 } & 23.71 & 0.73 \\ \text { KPF 17.3 } & 32.09 & 1.46 \\ \text { KPF 21 } & 18.87 & 0.73 \\ \text { KPF 22 } & 16.83 & 0.34 \\ \text { KPF 23.6 } & 46.93 & 1.13 \\ \text { KPF 24.5 } & 34.59 & 1.31 \\ \text { KPF 26.8 } & 35.83 & 0.78 \\ \text { KPF 30.5 } & 25.43 & 0.53 \\ \text { KPF 32.2 } & 20.57 & 0.49 \\ \text { KPF 34.6 } & 26.10 & 1.02 \\ \text { KPF 42.7 } & 13.64 & 0.27 \\ \text { KPF 44.1 } & 17.54 & 0.68 \\ \text { KPF 47.9 } & 4.45 & 0.05 \\ \text { KPF 60.4 } & 9.24 & 0.55 \\ \text { KPF 64.3 } & 18.97 & 0.23 \\ \text { KPF 70.4 } & 14.76 & 0.47 \\ \text { KPF 82.9 } & 42.90 & 1.18 \\ \text { KPF 83.2 } & 14.50 & 1.18 \\ \text { KPF 85.5 } & 27.88 & 0.44\end{array}$



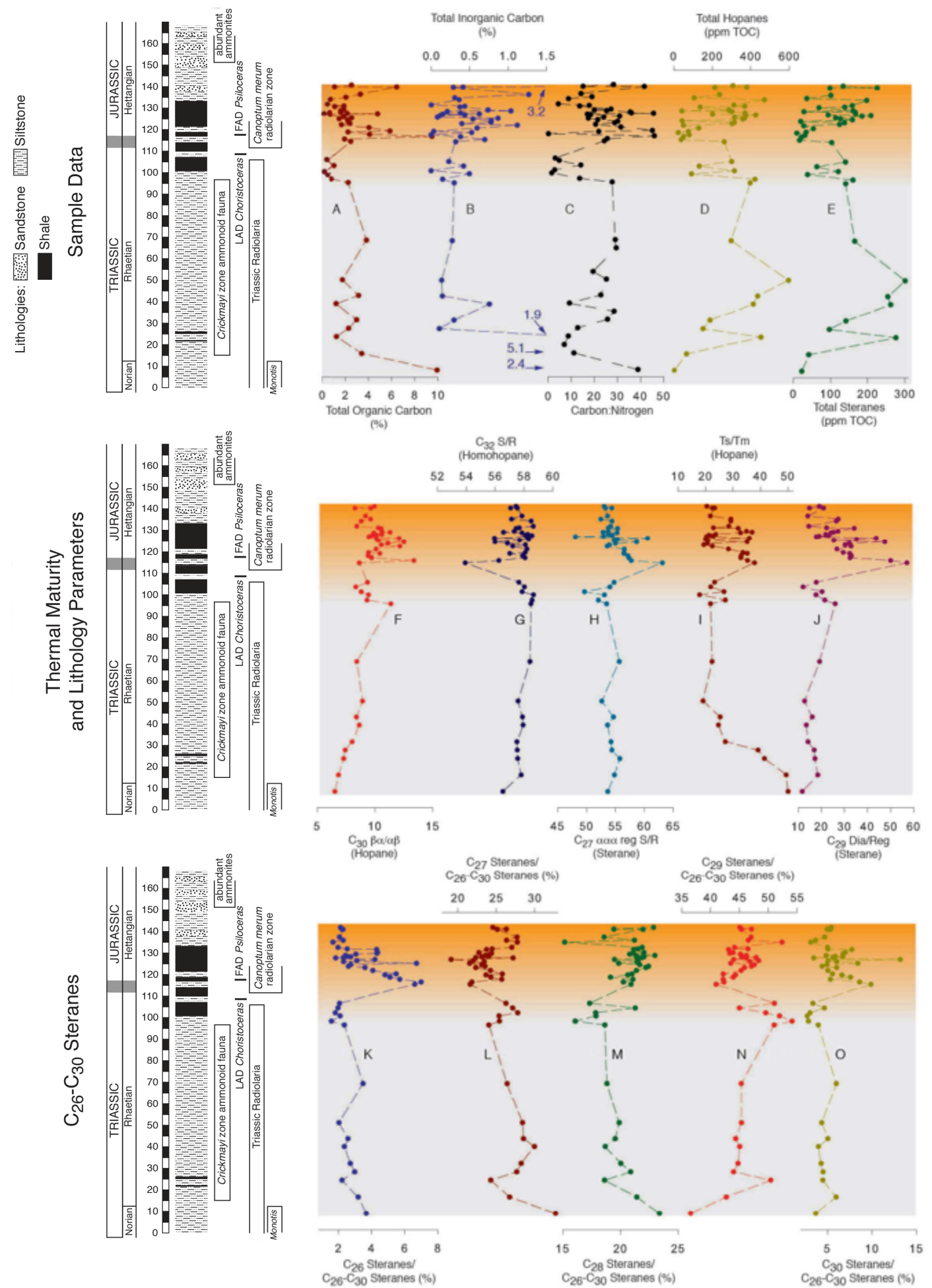

Data Repository Figure 1. (A-E) Elemental data and biomarker concentrations; (F-J) thermal maturity and lithology parameters; (K-O) $\mathrm{C}_{26}-\mathrm{C}_{30}$ sterane ratios. Thermal maturity is further discussed in Section S2. The complete sterane data show that $\mathrm{C}_{26}$ and $\mathrm{C}_{30}$ steranes comprise a minor fraction of the sterane record. 


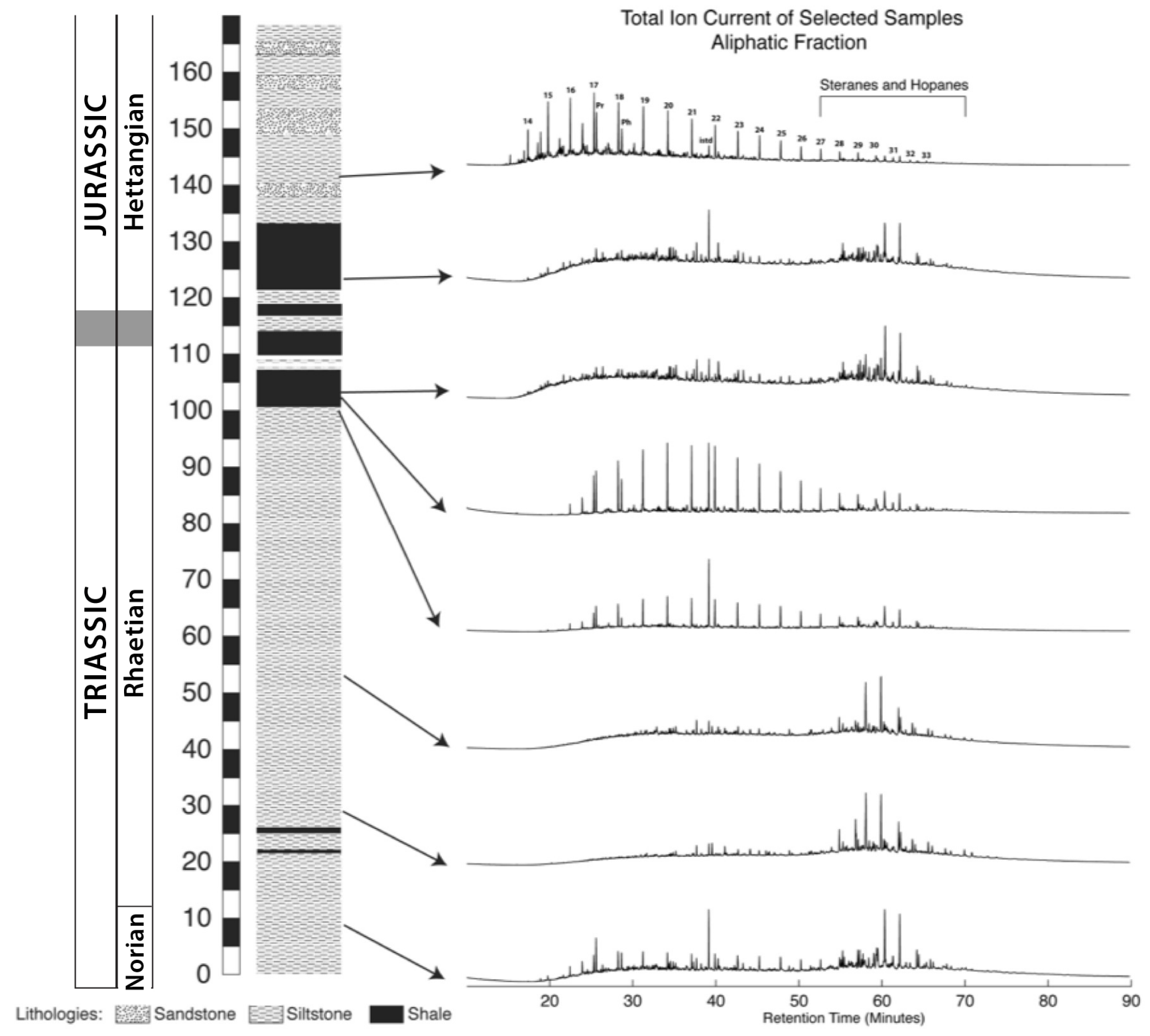

Data Repository Figure 2. Total Ion Chromatogram (TIC) of the aliphatic hydrocarbon fraction of representative samples. Some samples exhibit considerable evidence of biodegradation, as indicated by low alkane:(hopanes+sterane) ratios, and an elevated baseline. To overcome biodegradation we focused on the analysis of hopanes, steranes, and aryl isoprenoids by MRM-GC-MS. Biomarker ratios were used to account for the level of biodegradation present in each sample. Numbers indicate carbon number of $n$ alkanes, "Pr" pristane, "Ph" phytane,"istd" internal standard. 


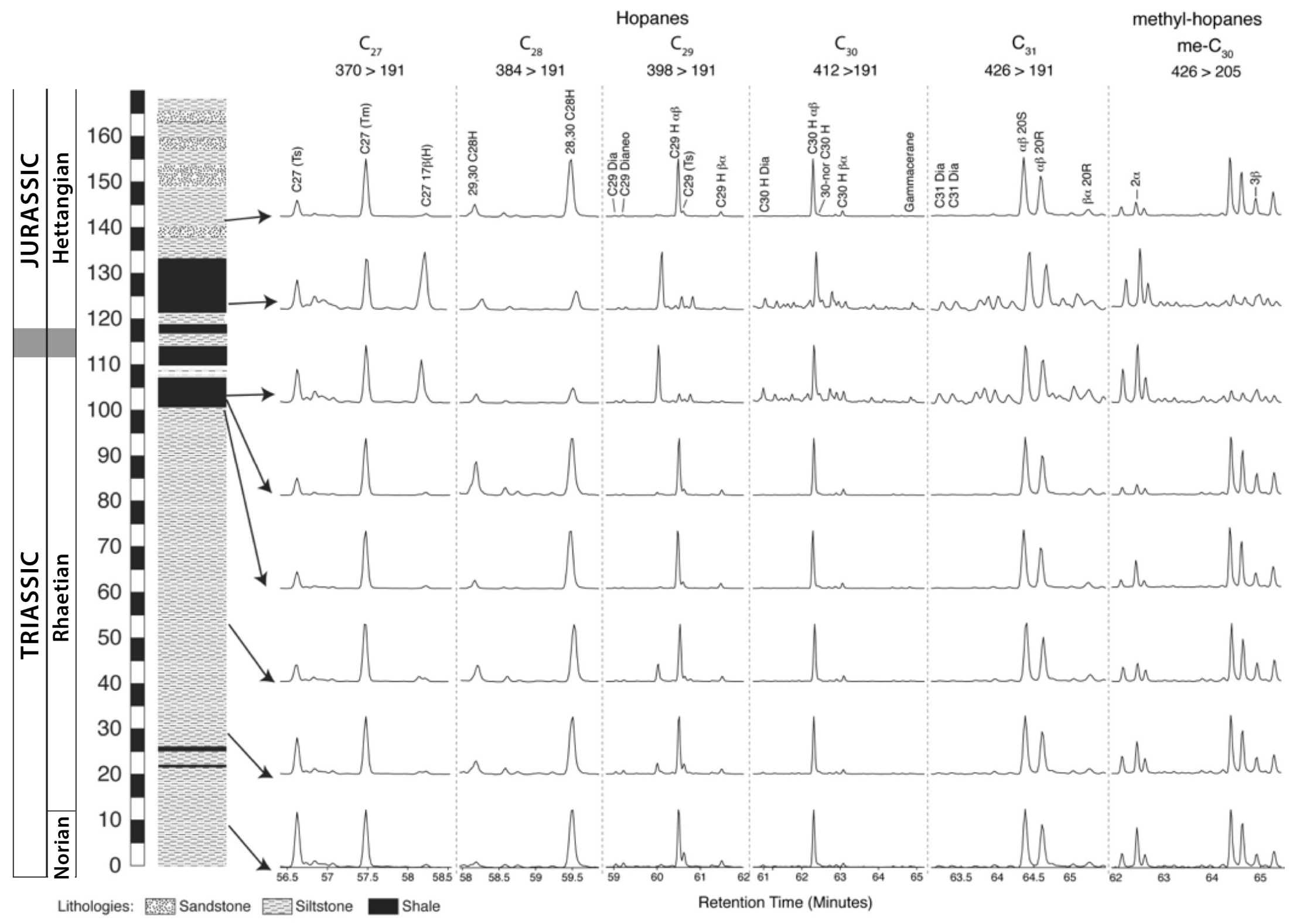

Data Repository Figure 3. GC-MRM-MS transitions of desmethyl and methyl pentacyclic triterpanes, plus gammacerane. 


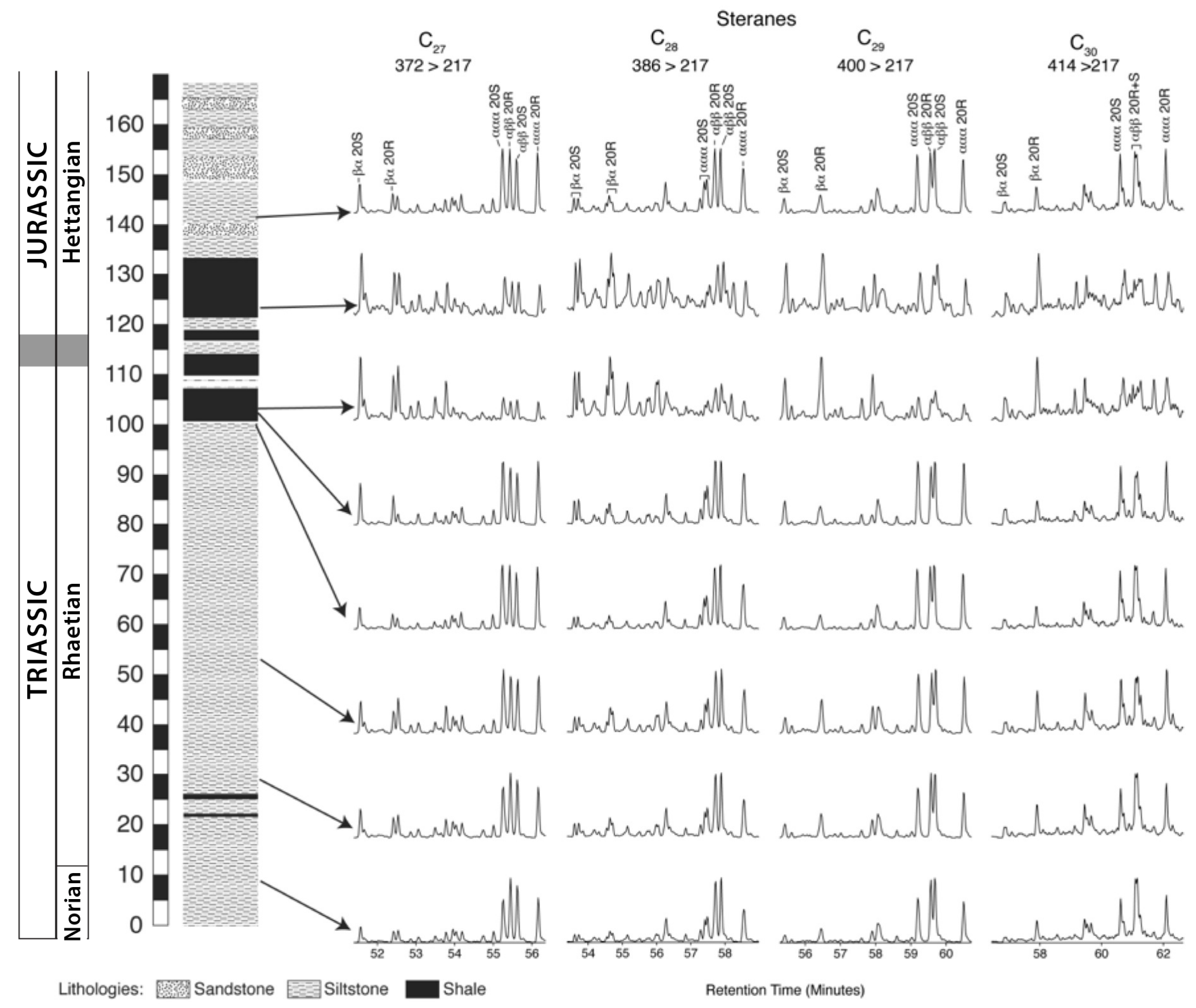

Data Repository Figure 4. MRM-GC-MS traces of $\mathrm{C}_{27}-\mathrm{C}_{30}$ steranes. 


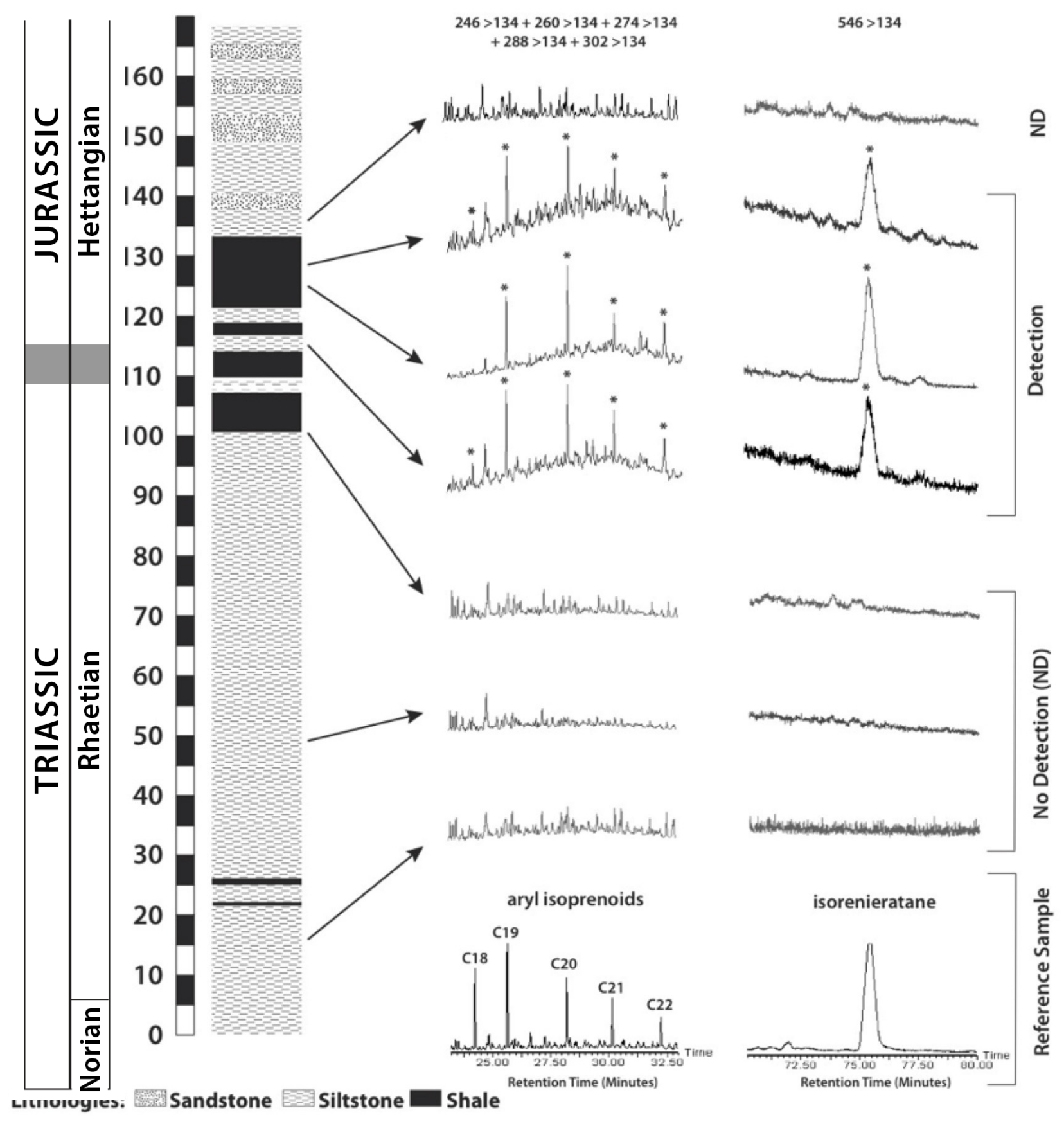

Data Repository Figure 5. GC-MRM-MS transitions of aryl isoprenoids (left) and isorenieratane (right) in selected representative samples. Data were compared to samples from two time intervals of widespread anoxia, the Cenomanian-Turonian Boundary in Central Jordan (bottom chromatogram; Sepulveda et al., 2009) and the end-Permian extinction from Meishan, China (data not shown; Cao et al., 2009). Numbers indicate carbon atom numbers for aryl isoprenoids, and * denotes unambiguously detected peaks used for integration. Numbers on top of chromatograms indicate MRM transitions used for compound identification. 


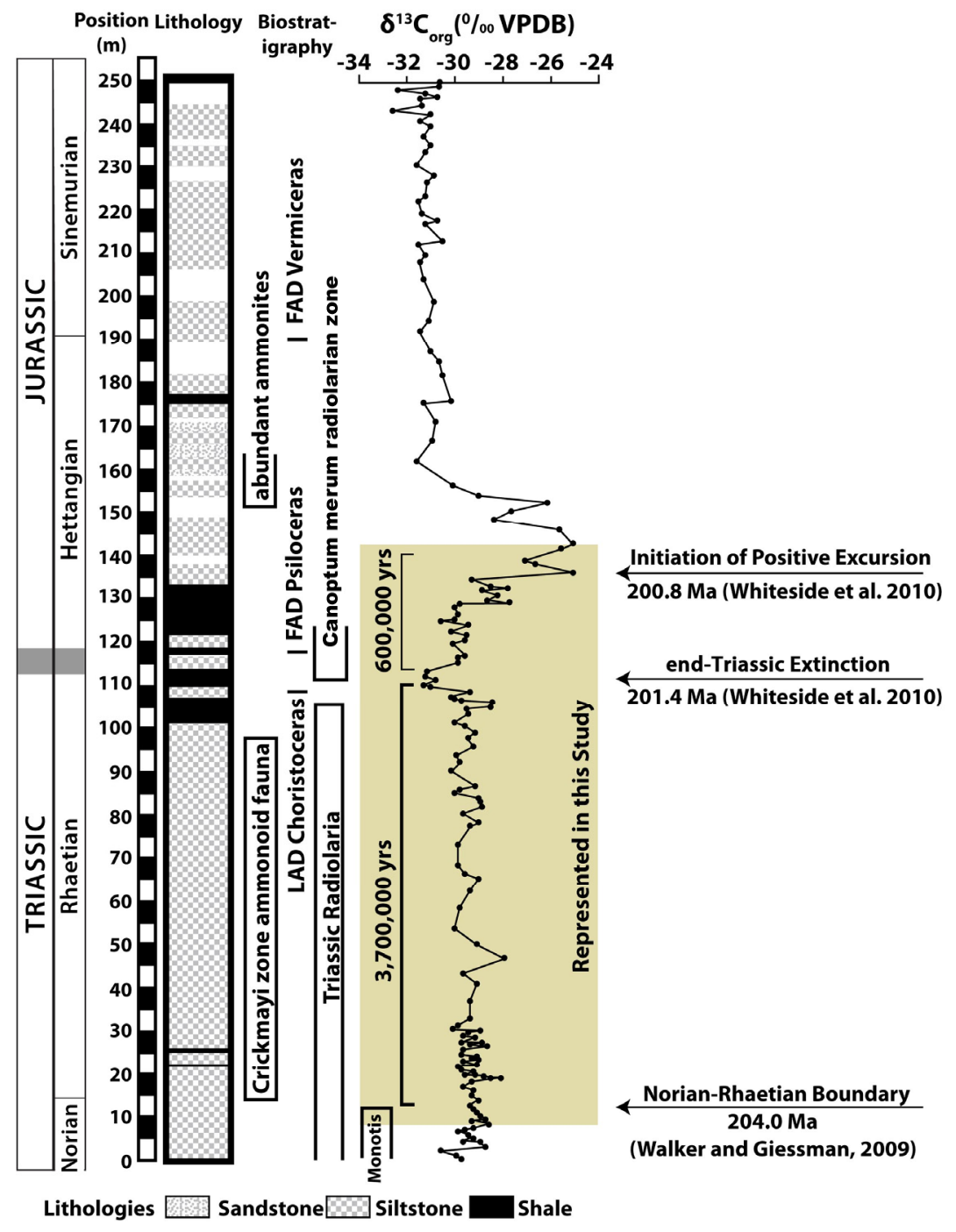

Data Repository Figure 6. Time span represented by this study (colored area) in the context of the complete carbon isotope profile from Kennecott Point. Modified from Williford et al. (2009). 